(C) 2016

\title{
Perfecting appraisal plan of quality and safety of bee honey in Ukraine
}

M. Bashchenko,

Academician of the National Academy of Sciences of Ukraine, Doctor of Agricultural Sciences

National Academy of Agrarian Sciences of Ukraine

V. Postoyenko,

doctor of agricultural sciences

L. Lazareva

National Scientific Center "Institute of Beekeeping named after P.I. Prokopovich"

The purpose. Development of approaches to perfecting appraisal plan of quality and safety of bee honey in Ukraine and its harmonization with international demands. Methods. Quality and safety of honey was probed according to State standard 4497:2005 «Honey natural. Commercial specification». Results. Comparative analysis of national standards of quality and safety of honey and international demands has shown that existing differences in demands cause ecessity of perfecting and harmonization of domestic legislative baseline. Conclusions. Analysis of longterm probes of honey of various botanical parentages and from different regions of Ukraine shows that honey of domestic producers has high factors of quality and origin. The expediency is shown of keeping more rigid the following parameters of quality: content of inverted sugars, GMF, and activity of diastase. That will allow protecting home market from import of poor-quality honey. Necessity is justified of fitting national normative baseline concerning grading honey on quality factors (humidity, electrical conductivity, total sum of sugars and safety) with world demands. That will promote overgrowth of export potential of Ukraine.

Key words: honey, quality factors, origin, safety.

Quality and food safety related to the national priorities of any state. They are one of the key moments in the mechanism of regulation of export-import operations in respect of a product. This area of society becomes multifaceted social, economic and political aspects. [9]

Ukraine is the group leader manufacturer and exporters of honey and collects it at $5 \%$ of global volume, which is $70000-75000$ t. The importance of honey bees due to domestic demand and consumption of both industrial raw materials and foreign exchange earnings from its implementation on the world market in terms of high competitiveness [1]. Therefore, improving the system of assessing the quality and safety of honey bee uu and harmonization with international requirements is extremely important task for Ukraine. Addressing this question will help: First, the needs of the population quality product, and secondly, to protect the domestic market from low-quality imports, thirdly, increase eksportospromozhnosti country.

In Ukraine, the quality and safety of honey bee regulated ISO 4497 "Honey", which was developed in 2005, NSC "Institute of beekeeping them. P.I.Prokopovycha "and entered into force on 01.01.2008. The standard at the time played a positive role in the establishment, development and operation of the system of assessing the quality and safety of honey and largely brought it to the requirements of international standards. In recent years, the Institute conducted research on a wide range of quality evaluation of different botanical origin of honey produced in various regions of Ukraine, and worked out a significant experimental data justifying the need to improve the existing system [5,6,7].

In this regard, the aim of this work is to develop approaches to improve the system of assessing the quality and safety of honey bee in Ukraine and its harmonization with international requirements. 
Materials and methods of research. Sampling of honey bee different botanical origin (acacia, lime, buckwheat, sunflower, with grasses) and from different regions of Ukraine conducted the laboratory staff quality and product safety beekeeping NSC "Institute of beekeeping them. PI Prokopovich. A comparative analysis of the quality and safety of honey bee in Ukraine existing in other countries. The quality of honey organoleptic and physico-chemical parameters determined by methods according to ISO 4497: 2005 "Honey. Specifications ". [10]

The data were treated statistically using the program "Microsoft Excel-15,0 calculation of the arithmetic mean (M), standard deviation (m) [8].

Results. Improvement of assessing the quality and safety of honey bee is inextricably linked with the question of its classification. Comparative analysis of legislation in the EU and Ukraine shows the presence in them of different classification systems honey bee (Table 1).

Table 1. Classification of honey bee under existing standards in Ukraine and the EU [15].

\begin{tabular}{|c|c|c|}
\hline Classification: & Ukraine & EC \\
\hline birth & $\begin{array}{l}\text { 1.Kvitkovyy (Monophlore } \\
\text { or Polyphlore): } \\
\text {-hatunok higher } \\
\text {-hatunok } 1 . \\
\text { 2.Kvitkovyy with impurities } \\
\text { Padi. }\end{array}$ & $\begin{array}{l}\text { 1.Kvitkovyy or nectarial. } \\
\text { 2. valleys. }\end{array}$ \\
\hline $\begin{array}{l}\text { method } \\
\text { of production }\end{array}$ & $\begin{array}{l}\text { 1.Stilnykovyy. } \\
\text { 2.Presovanyy. } \\
\text { 3.Tsentryfuzhnyy. }\end{array}$ & $\begin{array}{l}\text { 1.Stilnykovyy. } \\
\text { 2. In cell plates. } \\
\text { 3. Cast. } \\
\text { 4. Extracted/extracted. } \\
\text { 5.Presovanyy. } \\
\text { 6.Filtrovanyy }\end{array}$ \\
\hline appointment & & Baking. \\
\hline
\end{tabular}

Thus, the classifier Ukraine left index that exists for many food - this grade. In the EU there is no milk first or second grade milk is natural. So with honey or is a natural or a product of honey (or raw materials containing honey).

By way of production in accordance with the requirements of national standards no division honey, fused with slices of honeycomb extracted/extracted, filtered. We consider it appropriate to agree to the EU requirements for the classification of honey in origin, method of manufacture, destination and remove requirements of Soviet laws on separation of honey varieties.

For the purpose of EU standards separately labeled honey for further technological processing (eg confectionery or bakery industries). Typically in Meda baking quality product below the natural honey. Therefore, there is a problem for our market concerning the free flow of honey baking (technical, industrial) with the EU in our country in the form of natural honey. This can create unhealthy competition our high quality product and replacing it with a cheaper but lower quality honey. Now this problem is considered and solved at the state level. Thus, the Ministry of Agriculture together with the Ministry of Health of Ukraine is preparing an act to amend the requirements of quality parameters of honey depending on the destination, which will be resolved the issue of harmonization of requirements for honey intended for human consumption (Honey) and industrial needs. [11]

Therefore, we consider it appropriate to develop additional requirements for honey baking, for example, this indicator as content hidroksymetylforfurolu (GMP), which should not be higher than $25 \mathrm{mg} / \mathrm{kg}$. Higher 
values indicate his unnatural (change the quality during storage, heat treatment, fraud, etc.) product. The requirements of EU standards to allow baking honey HMF content to $40 \mathrm{mg} / \mathrm{kg}$. All this is not a quality product can get to our market. With this, in our opinion, you must enter the yields of HMF for natural honey intended for human consumption is not more than $10 \mathrm{mg} / \mathrm{kg}$, and for industrial needs (baker's honey) -not more than $25 \mathrm{mg} / \mathrm{kg}$, which, in our opinion, make it impossible revenues market honey dubious quality. So, most of samples of honey coming to the institute for certification, GMP content is in the range of $2.7-4.1$ $\mathrm{mg} / \mathrm{kg}$ (Table. 2).

Table 2. Quality of different botanical origin of honey

\begin{tabular}{|l|c|c|c|c|c|}
\hline Indicator & $\begin{array}{l}\text { Acacia, } \\
\mathrm{n}=20 ;\end{array}$ & linden, $\mathrm{n}=25$ & $\begin{array}{l}\text { With sunflowe } \\
\mathrm{n}=50\end{array}$ & Buckwheat, $\mathrm{n}=14$ & $\begin{array}{l}\text { With grasses } \\
\mathrm{n}=14\end{array}$ \\
\hline Water content,\% & $17.2 \pm 0.1$ & $17.4 \pm 0.1$ & $17.6 \pm 0.08$ & $18.0 \pm 0.16$ & $17.4 \pm 0.7$ \\
\hline $\begin{array}{l}\text { Diastazna activity } \\
\text { od.Hote }\end{array}$ & $11.5 \pm 0.6$ & $26.8 \pm 0.7$ & $19.9 \pm 0.5$ & $38.7 \pm 1.7$ & $24.1 \pm 4.9$ \\
\hline Sugar content,\% & $85 \pm 2.4$ & $88.2 \pm 0.2$ & $90 \pm 0.3$ & $87.7 \pm 4.6$ & $83.4 \pm 2.5$ \\
\hline Sucrose content,\% & $2.8 \pm 0.3$ & $2.4 \pm 0.1$ & $2.5 \pm 0.1$ & $1.9 \pm 0.02$ & $2.0 \pm 0.03$ \\
\hline $\begin{array}{l}\text { Hydroxymethylfurfural } \\
\text { content mg/kg }\end{array}$ & $3.2 \pm 0.5$ & $2.7 \pm 0.5$ & $3.0 \pm 0.3$ & $2.9 \pm 0.2$ & $4.1 \pm 3.4$ \\
\hline Proline content, $\mathrm{mg} / \mathrm{kg}$ & $189.0 \pm 9.2$ & $409.9 \pm 10.0$ & $249.6 \pm 6.6$ & $529.6 \pm 28.0$ & $318.6 \pm 69.1$ \\
\hline
\end{tabular}

In recent years, the international community increased requirements for bee products (honey bee) for their naturalness and safety. They are recorded in the terms Codeh Alimtarius CODEH STAN12-1981, Rev.2 (2001), in a more expanded form in Council Directive 2001/95 EC of the general product safety, Council Directive 2001/110 of 20 December 2001 (Council directive 2001/110/EC of 20 December 2001 relating to honey Official Journal of the European Communities L 10, 12. 1. 2002, P.47-52), the EU Charter 178/2002-General laws food and other documents on which A special international commission of honey (international honey Commision), initiated by Apimondia in 1990., developed specific provisions for apiculture products (Table. 3 ).

Table 3. Quality of honey standards of different countries.

\begin{tabular}{|l|c|c|c|c|c|c|c|}
\hline Indicator & $74 / 409 / E C$ & $\begin{array}{c}\text { Den } \\
\text { mark }\end{array}$ & Cuba & Poland & Japan & Austria & EC/9 \\
\hline Water content,\% not more & 21 & 21 & 21 & 20 & 21 & $\begin{array}{r}17.5- \\
18.5\end{array}$ & 20 \\
\hline Reducing sugar, at least\% & 80.0 & 82.0 & 82.0 & 87.5 & 82.0 & 87.5 & 60.0 \\
\hline Sucrose, no more than\% & $5-10$ & 6.3 & 6.3 & 6.2 & 6.2 & 10 & 5 \\
\hline $\begin{array}{l}\text { Diastazne number for dehydrated } \\
\text { matter), not less than\% }\end{array}$ & $3-8$ & 10 & 10 & 10.4 & - & 10 & $3-8$ \\
\hline $\begin{array}{l}\text { Hydroxymethylfurfural content of } \\
\text { not more mg/kg }\end{array}$ & 40 & 20 & 40 & 30 & 50 & $10-15$ & 40 \\
\hline $\begin{array}{l}\text { The total acidity of not more ml } \\
\text { 1M NaOH }\end{array}$ & 4.0 & 4.0 & $1-4$ & 4.0 & 4.0 & 4.0 & 5.0 \\
\hline $\begin{array}{l}\text { од The activity of invertase, from } \\
\text { Electrical conductivity, mS/cm }\end{array}$ & & & & & & & $10-$ \\
\hline
\end{tabular}

One of the main indicators of maturity of honey is the content of water. 
According to many researchers and existing standards, the water content in the composition of honey varies from 14 to $21 \%$ [2,4,12]. If the moisture content exceeds $20 \%$, it indicates immaturity of honey. Immature honey is not suitable for long term storage, quickly sour and spoil [3]. In assessing this figure as honey based on years of research and statistics, we can confidently say that Ukrainian honey moisture content of $20 \%$ is reasonable (for $95 \%$ of the samples of mature honey\% moisture was $<18 \%$, Tab. 2 ) [5, $6,7]$.

Requirements of national standards and the EU to physical and chemical properties of honey are shown in Table 4. First of all, attention is drawn to the fact that the requirements of European standards is not an indicator pollen analysis. But honey export customers must demand its implementation. We believe that the presence of this indicator in the overall evaluation of the quality of honey makes Ukrainian honey more attractive to customers and provide benefits. Therefore, this measure should be left to national requirements with regard to product quality and to amend the $\%$ value species of pollen grains of different botanical origin of honey.

Table 4. Physico-chemical properties of honey according to national and EU standards.

\begin{tabular}{|c|c|c|c|}
\hline Indicator & $\begin{array}{l}\text { Requirements ISO } \\
\text { (Top/first brand) }\end{array}$ & $\begin{array}{l}\text { Proposals to } \\
\text { improve standards }\end{array}$ & $\begin{array}{l}\text { EU } \\
\text { requirements }\end{array}$ \\
\hline pollen analysis & $\begin{array}{l}\text { The presence of pollen } \\
\text { grains }\end{array}$ & + & \\
\hline $\begin{array}{l}\text { The species composition of } \\
\text { pollen grains, at least } \%\end{array}$ & $10 / 10$ & $30^{*}$ & $20-30$ \\
\hline Water content,\% not more & $18,5 / 21$ & 20 & 20 \\
\hline $\begin{array}{l}\text { Mass share of renewable } \\
\text { sugars (for dehydrated matter), } \\
\text { not less than } \%\end{array}$ & $80,0 / 70,0$ & 80 & 60 \\
\hline $\begin{array}{l}\text { Mass fraction of sucrose } \\
\text { (dehydrated to matter), no more } \\
\text { than\% }\end{array}$ & $3,5 / 6,0$ & 3.5 & 5.0 \\
\hline $\begin{array}{l}\text { Diastazne number (for } \\
\text { dehydrated matter), not less } \\
\text { than\% }\end{array}$ & $10 / 15,0$ & $15^{\star *}$ & 8 од. Шаде \\
\hline $\begin{array}{l}\text { Hydroxymethylfurfural } \\
\text { content of not more } \mathrm{mg} / \mathrm{kg}\end{array}$ & $10,0 / 25,0$ & 10 & 15 \\
\hline $\begin{array}{l}\text { Acidity, milliequivalents of } \\
\text { sodium hydroxide }(0.1 \mathrm{~mol} / \mathrm{L}) \text { for } \\
1 \mathrm{~kg}, \max \end{array}$ & $40,0 / 50,0$ & 40 & 50 \\
\hline $\begin{array}{l}\text { Proline content, mg per } 1 \mathrm{~kg} \text {, } \\
\text { not less }\end{array}$ & $300,0 / 300,0$ & 160 & 160 \\
\hline $\begin{array}{l}\text { Electrical conductivity, mS / } \\
\mathrm{cm}\end{array}$ & $0,2-1,0 / 0,2-1,5$ & 1.0 & 0.8 \\
\hline
\end{tabular}

${ }^{*}$ Honey acacia composition of pollen grains, at least $25 \%{ }^{* *}$ for acacia honey diastazne number at least 5 units. Goethe.

An important indicator of the quality of honey is sugar content and activity of enzyme systems - invertase, diastase, maltose, catalase and others. According to the requirements of ISO 4497: 2005 sugar content in honey can vary from sucrose to 
$3,5 \%$ in the highest quality honey and 1 to 6.0 for the brand. [10] EU standards requirements include sucrose content of $5 \%$. In harmonize the requirements for this indicator is advisable to leave it at the level of European standards. Renewable content of sugars as the precious indicator of honey quality in national standards is almost $20 \%$ higher than the requirements of EU standards, which is one element of protecting the domestic market from non-quality. Unfortunately honey is one of the foods most often exposed to fraud as a quantitative assessment of the content of biologically active substances such as enzymes that characterize the quality and naturalness of honey should not be underestimated wake. According to the requirements of the current national standard diastase activity must be at least 15 and 10 units. Goethe honey and higher quality persheho respectively, and acacia honey - at least 5 units. Goethe. According to international requirements after diastase activity of honey should be not less than 8

Schade units, except baker's honey, but not less than 3 Schade units for low natural honey diastase content (acacia honey and citrus). Research Methodology honey diastase activity according to the national standard is different from the foreign, causing the divergence of the results. In this case is necessary to harmonize methods of measurement.

Furthermore, in some European countries further regulate the activity of invertase, which is a sensitive indicator of the naturalness of honey. We know that violation of conditions of storage and temperature factor accompanied by a sharp decrease in the activity of this enzyme. Therefore, the requirements for determining diastase should supplement control invertaznoyi activity (Zyhentalera method to DIN 10759-1) [14].

Amino acids are the most important components of honey. Indicators of content used as criteria of naturalness and maturity of the given product. However, today in the world there is no uniform requirements for quantitative parameters of their content in the product. For example, the Russian state standards determined that the boundary between honey and sugar-containing products is the concentration of proline in not less than $160 \mathrm{mg} / \mathrm{kg}$. In the European Union, in particular Germany, the requirements for the minimum number of proline more stringent. According to the agreement of the German Union of Beekeepers proline content in honey should not be less than $180 \mathrm{mg} / \mathrm{kg}$, and for enzymatic weak honey (rape, honey, beekeeping), this figure could be lower $[13,15]$. The literature also found information that truly high-quality honey can contain and $550 \mathrm{mg} / \mathrm{kg}$ proline [16]. In Ukraine proline content in honey, in accordance with the requirements of ISO 4497: 2005

"Honey. Specifications ", must be at least $300 \mathrm{mg} / \mathrm{kg}$. For honey competitiveness both in the domestic and foreign markets consider it appropriate to agree to the EU requirements proline content in honey should not be less than $180 \mathrm{mg} / \mathrm{kg}$. Requirements for proline content in honey also be adjusted allowing for the botanical origin of honey.

According to the requirements of ISO conductivity highest quality honey - 0,2-1,0 mS/cm, first grade - 0,2$1,5 \mathrm{mS} / \mathrm{cm}$, whereas the international requirements of no more than $0,8 \mathrm{mSm} / \mathrm{cm}$. Electrical conductivity refers to indicators that suggest the origin of honey, honey from honeydew distinguish nectarial. Tough figure $0.8 \mathrm{mSm} / \mathrm{cm}$ ignores features honeys of different botanical origin when our data $20 \%$ of quality honey can be elektroprovodnosti rate above $1[5,6,7]$.

Also of quality, it is vital to study the safety of honey. According to EU standards, they are the determining residual amounts of antibiotics, sulfanilamide drugs, radionuclides, heavy metals, pesticides and so on.

Table 5. Requirements concerning importers MAC antibiotics in honey, $\mathrm{Pb}(\mathrm{mg} / \mathrm{kg})$

\begin{tabular}{|l|l|l|c|}
\hline Name antimicrobial & EC & India & Ukraine \\
\hline Streptomycine & 5 & 5 & not allowed \\
\hline Tetracyclines & 5 & 5 & not allowed \\
\hline Sulfonamides & 5 & 0.5 & 10 \\
\hline Chloramphenicol & $\mathbf{0 . 1}$ & 0.3 & 0.3 \\
\hline
\end{tabular}




\begin{tabular}{|c|c|c|c|}
\hline $\begin{array}{c}\text { Nitrofuranes (AOZ- } \\
\text { AMOZ) }\end{array}$ & 0.5 & 0.5 & 0.6 \\
\hline Nitroimidazoles & 0.2 & & \\
\hline
\end{tabular}

From Table. 5 clearly visible existing differences on the content of residual amounts of antimicrobial agents in the legislation of Ukraine and the EU. Thus, the presence in honey streptomycines and tetracyclines according to national standards is allowed. For other indicators are more stringent requirements of the EU. Harmonization of these and other safety indicators natural honey with world standards the EU will increase the export potential of our country.

\section{Conclusions and recommendations for further development}

1. Analysis of long-term studies of different botanical origin of honey and from different regions of Ukraine shows that domestic producers of honey has high quality and naturalness.requirements established they do not match in many ways, proving the need to improve and harmonize national legislation.

3. Expediency leave more stringent quality parameters such as the content of inverted sugars, HMF, diastase activity that will protect domestic market from import of low- quality honey.

4. The necessity to comply with international requirements of the national regulatory framework with the classification of honey in terms of quality - humidity, conductivity, total sugars and safety, which will help increase export potential of Ukraine.

\section{Bibliography}

1.Bazhyn A. Purchase, sale and export Meda/NA.Bazhyn//Pasichnyk.-2015.-№10.- S.8-10

2. Kamler F. How to get quality medical nektarnыy//Pasika.-1997.-№11.-p.19.

3. Kerimov KY Determination of water content and udelnoho Vesa Meda//Pchelovodstvo.- 1957.-№9.S.33-34.

4. The question Kuznetsov A. K turkestanskyh medovA.Kuznetsov quality, P.E.Ermolaeva //Tr.Turkm.SHY ym.Kalynyna., Ashgabat, 1963.-T. XII.-S.297-298.

5.Lazaryeva L.M.Rezultaty study quality honey from different southern and northern regions of Ukraine /L.M. Lazarev, V. Kovtun, ZV Shapoval, A. Smith//Problems zooengineering and veterinary medicine: Coll. Science. Labors, Vol. 30 Ch. 2. Veterinary nauky.- H., 2015.-S.256-259.

6.Lazaryeva Results of the study as honey obtained in the western and eastern regions of Ukraine/LN. Lazarev, V. Kovtun, ZV Shapoval, A. Smith//Bulletin of Sumy th. Agrarian Univ series "Veterinary Medicine". Vol. 7 (37) .- Amounts 2015-S.93-97.

7.Lazaryeva Analysis of the quality of honey Western Ukraine/LN. Lazarev, V. Kovtun, LI. Shtanhret / / Veterinary Medicine: mizhvid. temat. Science. zb.- Vyp.101.-H., 2015 S.57-59.

8.Mazur T. The constant mathematical processing methods of quantitative indicators/T. Mazur//Vet. Medicine Ukrainy.-1997.-№9.-S.35-37.

9.Marenych MM Quality assurance and food safety in the EU. International legislation on the food chain and the potential of Ukraine according /M.M.Marenych,S.V data standards. Aromchiy, NS Maryuha X [electronic resource] - Mode of access: htt://77.121.11.22/ekolib/8/2.dok.

10. Honey. Specifications: ISO 4497: 2005 - Enter. the first time; acting on 2005-12-28. - K: State Committee of Ukraine, 2007. - III, 22 pp., Inc. cover. : Table. ; $29 \mathrm{~cm}$. - (Nat. Standard of Ukraine).

11.Rutytskaya V. Ukraine-European leader in the production of honey .// Pasichnyk. - 2015. - №10.-S.3-4

12. Dark VA Technology of products pchelovodstva. / V.A.Temnov.-M., 1965, S.192.

13. Chudakov Technology pchelovodstva of products/VG Chudakov.-M .: Kolos, 1979.- $160 \mathrm{p}$. 
14. Dustmann J.H. Zur botanischen Sortenbezechnung des deutsches Honig im D.I.B//Einheitsglas.1988.- ADIZ 22.-S.340-344.

15. Ohe W. Prolin als Kriterium der Reife des Honigs/. W. Ohe, J.H Dustmann, K. Ohe//Deutsch. Lebensm. Rundsch. - 1987.-S. 383-386.

16. Codex Alimentarius Commission. Revised Codex Standard for honey, Codex STAN 12-1981, Rev. ( 1987), Rev.2( 2001). Council Directive 2001|110|ES of 20 December 2001 relation to honey [Text]//Official Journal of the European Communities.-2002.-L.10.-P.47-52. 